\title{
Johann Joachim Winckelmann (1717- 1768): charting the artistic development of nations
}

Article

Accepted Version

Harloe, K. (2019) Johann Joachim Winckelmann (1717-1768): charting the artistic development of nations. History of Humanities, 4 (2). pp. 229-235. ISSN ISSN: 2379-3163 doi: https://doi.org/10.1086/704807 Available at https://centaur.reading.ac.uk/85597/

It is advisable to refer to the publisher's version if you intend to cite from the work. See Guidance on citing.

To link to this article DOI: http://dx.doi.org/10.1086/704807

Publisher: University of Chicago Press

All outputs in CentAUR are protected by Intellectual Property Rights law, including copyright law. Copyright and IPR is retained by the creators or other copyright holders. Terms and conditions for use of this material are defined in the End User Agreement.

$\underline{\text { www.reading.ac.uk/centaur }}$

\section{CentAUR}


Central Archive at the University of Reading

Reading's research outputs online 


\section{Johann Joachim Winckelmann (1717 - 1768): Charting the artistic development of nations.}

The first edition of the Geschichte der Kunst des Alterthums was published in Dresden at the very end of 1763. Its author, Johann Joachim Winckelmann, was a German antiquarian who had been resident in Rome since 1755 and had already made a name for himself with a string of shorter antiquarian publications on ancient art, including a famous essay titled Thoughts on the Imitation of Greek Works in Painting and Sculpture, an analytical catalogue of a major collection of engraved ancient gems and a series of reports on finds from the contemporary excavations at Herculaneum and Pompeii. ${ }^{1}$ The Geschichte - which was quickly translated into French and Italian - was Winckelmann's most innovative and influential work, and is the principal reason why he is traditionally dubbed both the 'father of art history' and the 'father of (classical) archaeology'. Its importance lies in Winckelmann's aspiration to furnish the blueprint for a new kind of cultural, social and political history of ancient peoples by combining both material and literary evidence into a new, comprehensive and causal analysis, of the rise, flourishing and decline of each people's artistic production.

The work is divided into two parts: in the first, Winckelmann provided a systematic, theoretical discussion of the 'origins of art and reasons for its diversity among peoples', followed by a comparative analysis of extant monuments of the ancient Egyptians, Etruscans, Greeks and Romans based upon drawing visual distinctions between chronologically successive styles. The second part offered a more detailed historical narrative of the 'growth, flowering and fall' of Greek and Roman art, drawing upon ancient literary sources in order to relate the changing fortunes of art in Greece and Rome to the 'external circumstances' defined in Part 1 as climate (topography and especially meteorological environment), education and ways of thinking, and political constitution - pertaining from the archaic period to the time of Justinian. In addition to a moderate climate, this narrative privileged political freedom, a competitive culture, and social respect accorded to artists as the principal causes of Greek artistic greatness. Part 2 of the Geschichte also included poetic descriptions of a number of the most famous Greco-Roman statuary to be found in Rome and Florence: works such as the Apollo Belvedere and the Niobe Group, which had been known and venerated since the Renaissance.

The Geschichte der Kunst des Alterthums found instant success: it received at least two French translations within Winckelmann's short lifetime, and an Italian translation followed in 1783. Winckelmann's shocking murder in Trieste at the age of 50, meant that subsequent editions were undertaken by committees of posthumous editors; it is debated how true they were to Winckelmann's intentions for revising his work, and whether or not they suppressed certain arguments, such as the acknowledgement that Greek sculpture was painted in colours, which were incompatible with northern European, neoclassical notions of ancestral Greek

\footnotetext{
${ }^{1}$ Johann Winckelmann, Gedancken über die Nachahumg der Griechischen Wercke in der Mahlerey und Bildhauer-Kunst (Dresden: Walther, 1755; revised and expanded edition 1756); Description des pierres gravées du feu Baron de Stosch (Florence: André Bonucci, 1760); Sendschreiben von den Herculanischen Entdeckungen, (Dresden: Walther). Numerous English translations of the Gedancken exist, of which the two most accessible are those contained in Johann Joachim Winckelmann, Writings on Art, ed. David Irwin (London: Phaidon, 1972) and in H.B. Nisbet, tr. and ed. German Aesthetic and Literary Criticism: Winckelmann, Lessing, Hamann, Herder, Schiller, Goethe (Cambridge: Cambridge University Press, 1985). The Sendschreiben now has an excellent, annotated English translation by Carol Mattusch: Johann Joachim Winckelmann, Letter and Report on the Discoveries at Herculaneum (Los Angeles: J. Paul Getty Museum, 2011).
} 
'purity'. ${ }^{2}$ But Winckelmann's arguments, especially his emphasis on the 'originality' and 'superiority' of Greek art above that of other peoples, also contributed strongly to the formation and development of those ideals.

Within classical scholarship, what have been identified as conflicting 'normative' and 'historicising' elements in the Geschichte have led in different directions. On the one hand, Winckelmann's attempt to combine material and literary/documentary evidence into a comprehensive, multi-perspective analysis of the ancient world points to the nineteenthcentury paradigm of classics as 'Altertumswissenschaft': the multidisciplinary and historicising study of the antiquity pursued by figures such as Barthold Niebuhr and August Boeckh. On the other, Winckelmann's emphasis on the superiority of Greek art and culture above those of other ancient peoples, and on the unparalleled edification offered by their study, set the scene for the turning away of Classics from the study of the ancient Mediterranean as a whole towards a narrower focus on Greece and Rome. Winckelmann's favouring of polygenetic rather than diffusionist accounts of the development of Greek art, and his views on the anatomical superiority of Greeks and southern Italians, also played a role in the nineteenth-century physical anthropology and the pseudo-science of 'race', though it must be noted that heredity plays little role in Winckelmann's system. His work provides a prominent and influential example of a kind of eighteenth-century historical theorising that takes the 'nation' or 'people', considered as an organic unity, as the primary unit of historical or cultural analysis, and = applies a developmental or evolutionary paradigm to cultural history. These assumptions have had far-reaching influence not only in humanities scholarship, but also in political thought. His claim that the beauty of Greek art was a product of Greek 'freedom' inspired French revolutionaries, while his open admiration for beauty, especially of the male form, was a stimulus to late nineteenth-century Aestheticism and the nascent European homosexual emancipation movement. ${ }^{3}$

One of Winckelmann's principal methodological innovations was his refinement of 'style analysis', or the attempt to attribute the production of material objects to artists, periods or places on the basis of visual characteristics. The notion that visual analysis could provide a key to distinguish between the artistic styles of different nations or peoples, and in the case of a single people to differentiate chronological phases in the development of the arts, was not original to Winckelmann. His older contemporary, the French antiquarian Comte Caylus, had anticipated it in his publication of his extensive collection of antiquities; Italian antiquarians such as Filippo Buonarotti had also experimented with using connoisseurial techniques to distinguish between the 'maniera' of different periods and nations. ${ }^{4}$ But Winckelmann

\footnotetext{
${ }^{2}$ Oliver Primavesi, “Artemis, Her Shrine, and Her Smile: Winckelmann’s Discovery of Ancient Greek Polychromy", in Circumlitio, The Polychromy of Antique and Mediaeval Sculpture, ed. Vinzenz Brinkmann, Oliver Primavesi, and Maz Hollein (Munich, Hirmer, 2010), 27-77.

${ }^{3}$ See Edouard Pommier, "Winckelmann et la vision de l'Antiquité classique dans la France des Lumières et de la Révolution", Revue de l'art 83 (1989), 9-20 ; Alex Potts, Flesh and the Ideal: Winckelmann and the Origins of Art History (New Haven and London: Yale University Press, 1994), 222-253 ; Stefano Evangelista and Katherine Harloe, 'Pater's 'Winckelmann': Aesthetic Criticism and Classical Reception', in Pater the Classicist, ed. Charles Martindale, Stefano Evangelista, and Elizabeth Prettejohn (Oxford: Oxford University Press, 2017), 63-80/

${ }^{4}$ See Alex Potts, Flesh and the Ideal: Winckelmann and the Origins of Art History (New Haven and London: Yale University Press, 1994) 72-81; Katherine Harloe, Winckelmann and the Invention of Antiquity: History and Aesthetics in the Age of Altertumswissenschaft (Oxford: Oxford University Press, 2013), 107-115 on the ancient and early modern precedents; on Caylus, Irène Aghion, Caylus, mécène du roi: collectionner les antiquités au XVIIIe siècle (Paris: Institut national d'histoire de l'art, 2002) and Marc Fumaroli, Le Comte de Caylus et Edme Bouchardon: Deux réformateurs du goût sous Louis XV (Paris: Somogy 2016); on historicization in early
} 
pushed stylistic discrimination further, on the basis of first-hand analysis of a larger corpus of ancient objects, than any of his predecessors had managed. His division of Greek art into the 'most ancient', 'high' (Phidian) and 'beautiful' (Praxitelean) styles finds its echo in the periodisation of archaic, early/late classical, and Hellenistic art still found in introductory textbooks today and had an equally strong influence on the display of classical archaeological collections in museums. ${ }^{5}$

Winckelmann was murdered in 1768, in the prime of his life and mid-way through the revisions to a second, expanded version of the Geschichte. Though this did appear posthumously in 1776, it is in the first edition that the methodological premisses, and aporias, of his 'system' are most evident. The axioms by which Winckelmann builds up his system, and their limitations, are particularly apparent in Part 1, Chapter 3 of the Geschichte der Kunst, in which Winckelmann treats of the art of the ancient Etruscans: an ancient Italian people, resident in and around what is now Tuscany and Umbria, who - so the ancient literary sources claimed - had formed a mighty civilization that dominated much of the Italian peninsula before the rise of Rome. Although Greek, rather than Etruscan, art provides the principal focus of the Geschichte, the Etruscans furnish both a linchpin of Winckelmann's historical narrative and a crucial test case for his working methods.

In part because of he could not read the Etruscan language, Winckelmann was more reliant in this chapter of the Geschichte than elsewhere upon conjectures formed from the surviving visual evidence. ${ }^{6}$ (As elsewhere, Winckelmann's discussion tends to be based upon objects to be found in the cabinets of connoisseurs and antiquarians, rather than unpublished material from new archaeological excavations or the sites themselves. Where the latter are cited, it is via the work of earlier authors such as Dempster, Buonarotti and Gori.) The ideological role of ancient Etruria in political competition between Florence and Rome across the early modern period had generated its own traditions of partisan scholarship, sometimes even backed up by forged objects. ${ }^{7}$ The Etruscans, as an important, historically attested civilization resident in Italy during the early centuries of Rome's rise, thus provided a particularly challenging case for both Winckelmann's attempt to distinguish the works of different peoples on the basis of visual characteristics and to articulate a systematic account of art's flourishing and fall in relation to general causes.

To follow Winckelmann in taking the latter first: because, as he concedes in the opening section, the Etruscans were blessed with a climate as favourable as that of the Greeks and with a non-despotic form of government, he must nonetheless account for what he considers the failure of their art to achieve as high a standard of beauty as that evident in Athens. His explanation, which appeals to the 'Melancholie' ('melancholy') and 'Aberglauben' ('superstition') inherent in the Etruscan temperament reflects the emphases on Etruscan

modern Italian antiquarianism, Gabriele Bickendorf, Die Historisierung der italienischen Kunstbetrachtung im 17. und 18. Jahrhundert (Berlin: Gebr. Mann, 1998).

${ }^{5}$ A.C. Smith, "Winckelmann, Greek Masterpieces, and Architectural Sculpture. Prolegomena to a History of Classical Archaeology in Museums," in The Diversity of Classical Archaeology, Studies in Classical Archaeology 1, ed. Achim Lichtenberger and Rubina Raja (Turnhout: Brepols, 2017), 23-45.

${ }^{6}$ It was Luigi Lanzi, a generation after Winckelmann, who would make the decisive breakthrough in study of the Etruscan inscriptions with his Saggio di lingua etrusca e di altre antiche d'Italia: per servire alla storia de' popoli, delle lingue e delle belle arti of 1789. See Corinna Riva, "The Freedom of the Etruscans: Etruria Between Hellenization and Orientalization," International Journal of the Classical Tradition 25, no.2 (June 2018): $101-126$.

${ }^{7}$ See Ingrid D. Rowland, “Annius of Viterbo and the Beginning of Etruscan Studies," in A Companion to the Etruscans, ed. Sinclair Bell and Alexandra A. Carpino (Chichester: Wiley-Blackwell, 2015), 433-445. 
religious practice that had informed both the ancient sources and early modern Etruscan scholarship and would have a long afterlife: in the 1870s, Nietzsche would refer to 'the dark voluptuousness of the Etruscans ('die finstere Wollüstigkeit der Etrusker'). ${ }^{8}$ The parallel course followed by Greek and Etruscan history also, so Winckelmann argues, accounts for similarities in their art in the earliest periods: hence Winckelmann confesses to difficulty in distinguishing securely between the archaic Greek and Etruscan styles. In the case of a several objects claimed as 'Etruscan' in Winckelmann's day, such as the 'Idolino' on display in Florence and the 'Etruscan vases' excavated in Nola, Winckelmann implies - without quite daring to declare - that they are Greek. ${ }^{9}$ Such uncertainty over the correct stylistic attribution of individual objects may also explain why Winckelmann first discusses what he judges to be the most significant surviving Etruscan artefacts in typological order: statues, reliefs, gems, coins and vases, before reordering them according to period style. His concluding claim that the stylistic similarity of Etruscan and Greek art means that his discussion of the Etruscans may serve as a preparation ('eine Vorbereitung') for that of the Greeks serves as a reminder of the universalizing premises of the Geschichte, which proceeds from the axiom that 'Art seems to have arisen in a similar way among all peoples who have practiced it' ('Die Kunst scheint unter allen Völkern, welche dieselbe geübet haben, auf gleiche Art entsprungen zu seyn'). ${ }^{10}$ Within Winckelmann's system it is historical differences, rather than similarities, that require historical explanation.

\section{BIBLIOGRAPHIC DETAILS}

First publication: Dresden, Walther, dated 1764.

Second (expanded) edition: Johann Winkelmanns Geschichte der Kunst des Alterthums. Nach dem Tode des Verfassers herausgegeben... von der kaiserlichen königlichen Akademie der bildenden Künste. Vienna, Akademie Verlag, 1776.

Recommended critical edition:

Johann Joachim Winckelmann, Schriften und Nachlaß:

Volume IV.1: Geschichte der Kunst des Alterthums: Text der 1. Aufl. 1764) 2002;

Text der 2. Aufl. 1776) 2009.

Volume IV.2: Katalog der Denkmäler. 2006.

Volume IV.3: Geschichte der Kunst des Alterthums: Allgemeiner Kommentar: Erste Auflage Dresden 1764: Zweite Auflage Wien 1776. 2007.

Edited by Adolf H. Borbein, Thomas W. Gaehtgens, Johannes Irmscher and Max Kunze. Mainz: Philipp von Zabern, 2002 - 2009.

Volumes IV.1 and IV.3 are available open-access at http://www.adwmainz.de/projekte/winckelmann-ausgabe/elektronische-publikation.html (accessed 27.02.18).

\footnotetext{
${ }^{88}$ Friedrich Nietzsche, "Homers Wettkampf," in Werke: Kritische Gesamtausgabe III.2, ed. Giorgio Colli and Massimo Montinari (Berlin: de Gruyter, 1973), 279. English translation: "Homer on Competition”, in Friedrich Nietzsche, On the Genealogy of Morality, ed. Keith Ansell-Pearson (Cambridge: Cambridge University Press, 1994)., 187-194, p. 188.

${ }^{9}$ On Winckelmann's re-evaluation of 'Etruscan' vases as 'Greek' see A.C. Smith, “Greek vases in Naples' ottocento laboratory of curiosity," in Winckelmann and Curiosity in the 18 ${ }^{\text {th }}$-Century Gentleman's Library, ed. Katherine.Harloe, Cristina Neagu and A.C. Smith (Oxford; Christ Church Library, 2018), 9-36.

${ }^{10}$ Winckelmann, History of Ancient Art, 111 = Geschichte der Kunst des Alterthums (Erste Auflage), 6.
} 
Recommended English translation (N.B. of first edition only): Johann Joachim Winckelmann, History of the Art of Antiquity. Introduction by Alex Potts, translation by Harry Francis Mallgrave. Los Angeles: Getty Research Institute, 2006.

Recommended selection for students:

1st edition, Part 1, Chapter 3: "Von der Kunst unter den Hetruriern, und unter ihren Nachbarn”, Sections I.i, I.iii, II, Conclusion.

German edition: Borbein et al. 2002, pp. $132-142,150-176,208$ (NB The first edition is printed on even pages only).

English translation: "Art of the Etruscans and their Neighbors," Winckelmann 2006, pp. 159 $-161,163-174,179$.

\section{RECOMMENDED READINGS}

Arbeid, Barbara, Stefano Bruni, and Mario Iozzo, eds. 2016. Winckelmann, Firenze e gli Etruschi. Il padre dell' archeologia in Toscana. Pisa: Edizioni ETS.

Bell, Sinclair and Carpino, Alexandra A. 2015. A Companion to the Etruscans. Chichester: Wiley-Blackwell.

Bickendorf, Gabriele. 1998. Die Historisierung der italienischen Kunstbetrachtung im 17. und 18. Jahrhundert. Berlin: Gebr. Mann.

Décultot, Élisabeth. 2000. Johann Joachim Winckelmann. Enquête sur la genèse de l'histoire de l'art. Paris : Presses universitaires de France. German translation 2004; Untersuchungen zu Winckelmanns Exzerptheften: Ein Beitrag zur Genealogie der Kunstgeschichte im 18. Jahrhundert. Tr. by Wolfgang von Wangenheim and Mathias Rene Hofter. Ruhpolding: Franz Philipp Rutzen Verlag.

Décultot, Élisabeth, et al., ed., Winckelmann. Moderne Antike. Munich: Hirmer Verlag, 2017. Disselkamp, Martin, and Fausto Testa, eds. 2017. Winckelmann Handbuch. Leben - WerkWirkung. Stuttgart: J.B. Metzler Verlag.

Harloe, Katherine. 2013. Winckelmann and the Invention of Antiquity: History and Aesthetics in the Age of Altertumswissenschaft. Classical Presences. Oxford: Oxford University Press.

Kaufmann, Thomas da Costa. 2001. "Antiquarianism, the History of Objects, and the History of Art before Winckelmann." Journal of the History of Ideas 62, no. 3: 523-41.

Marchand, Suzanne. 1996. Down from Olympus: Archaeology and Philhellenism in Germany, 1750 - 1970. Princeton: Princeton University Press.

Pommier, Edouard. 2003. Winckelmann, inventeur de l'histoire de l'art. Paris: Gallimard. 
Potts, Alex. 1994. Flesh and the Ideal: Winckelmann and the Origins of Art History. New Haven and London: Yale University Press.

Potts, Alex. 2006. "Introduction.” In Johann Joachim Winckelmann, History of the Art of Antiquity, tr. Harry Francis Mallgrave. Los Angeles: Getty Research Institute, 1-53.

Riva, Corinna. 2018. "The Freedom of the Etruscans: Etruria Between Hellenization and Orientalization." International Journal of the Classical Tradition 25, no. 2: $101-126$.

Schnapp, Alain. 1993. La conquête du passé: aux origins de l'archéologie. Paris : Editions Carré. English translation 1996: The Discovery of the Past: The Origins of Archaeology. London: British Museum Press. 